\title{
Governing the Governors: The Global Metagovernance of Fair Trade and Sustainable Forestry Production
}

Hannah Murphy-Gregory and Fred Gale, School of Social Sciences, University of Tasmania, Australia

\begin{abstract}
To promote environmentally sustainable corporate behaviour, a complex system of global private governance operates in which civil society groups play dominant roles. We argue that the concept of 'metagovernance' developed in the public administration literature helps scholars and practitioners make sense of the constellation of actors, structures, and processes that have emerged in the field of global private governance. This article advances the metagovernance research agenda by providing a comparative application of the concept to two global private governance schemes: the fair trade and sustainable forest product certification systems. We examine the key organisations, arrangements, and relationships that constitute these systems to demonstrate that metagovernance in this sphere is produced heterarchically: multiple organisations within global private governance schemes are mutually responsible for their own coordination. We argue that employing metagovernance as an analytical tool enables the identification and appraisal of the strengths and weaknesses of complex systems for 'the governance of governance' from a holistic perspective.
\end{abstract}

Keywords: Metagovernance; Global private governance; Certification; Labelling; Civil society organizations; Global standards; Fair trade; Forestry; Forest Stewardship Council; Fairtrade International

Acknowledgements: This paper was supported by the Governance, Activism and Social Licence Flagship Project of the Institute for the Study of Social Change at the University of Tasmania, Australia. We also gratefully acknowledge the anonymous reviewers and journal 
editor for their perceptive and extremely useful comments in refining this paper. 


\section{Introduction}

Metagovernance, a concept first employed to analyse national level governance (Rhodes 1997; Pierre \& Peters 2000; Jessop 2003), has recently been reconceptualised to consider governance occurring at the global level (see Glasbergen 2011; Derkx 2013; Derkx and Glasbergen 2014; Fransen 2015; Meulemann 2018). Referencing 'the governance of governance' metagovernance aims to explain and analyse efforts to oversee, manage, and coordinate complex, often fragmented, 'lower level' governance arrangements such as networks, quasimarkets, partnerships, self-regulation, and private commercial and non-profit entities (Rhodes 1997; Pierre \& Peters 2000; Jessop 2003; Sørensen 2006; Bell \& Hindmoor 2010; Bevir 2011; Torfing et al. 2012; Tollefson et al. 2012). This article advances the metagovernance research agenda by providing a systematic comparative application of the concept to two global private governance schemes: the fair trade and sustainable forest product certification systems. Global schemes such as these are considered 'private' because they are primarily led by business and civil society groups rather than governments. Given that these schemes typically operate beyond the reach of any one government's formal authority, the purpose of our case selection is to test the limits of the metagovernance concept (and, in some formulations, its supposed dependence on the 'shadow of hierarchy' and the exercise of governmental authority) in contexts where governments play peripheral roles. The aim of the article is to analyse what an empirical application of the metagovernance concept reveals about about how complex, global private governance schemes are sustained without governments at the helm. We find that an application of metagovernance to our cases reveals that no single actor provides metagovernance in global private governance, but rather the leading groups and the international standards bodies contribute to collective metagovernance in a heterachic, rather than hierarchic, fashion as they seek to adapt their schemes to existing and emerging 
experience. We argue that employing metagovernance as an analytical tool enables the identification and appraisal of the strengths and weaknesses of complex systems for the governance of governance - whether public or private, national or global - from a holistic perspective.

Underpinning our decision to focus on 'metagovernance' as opposed to one of several competing descriptors such as ‘orchestration' (e.g. Abbott \& Snidal 2009), 'network governance' (e.g. Betsill \& Bulkeley 2004), ‘collaborative governance’ (e.g. Ansell \& Gash 2008) and 'polycentric governance' (e.g. Ostrom 2010) is a desire to place the focus on the activities undertaken in the governance of governance rather than on specific actors and interactions (Ludwig and Kok 2018). Thus, for example, orchestration requires identifying an orchestrator who 'enlists one or more intermediary actors (the intermediaries) to govern a third actor or set of actors (the targets) in line with the orchestrator's goals' (Abbot \& Bernstein quoted in Ludig \& Kok 2018, 12) while 'network governance' involves “the 'management' of complex networks, consisting of many different actors from the national, regional and local government, from political groups and from societal groups (Kickert et al. quoted in Meuleman 2018, p. xiii). We are concerned that zeroing in on an orchestrator's role may underplay and/or distort other activities also taking place. Similarly, while network (and collaborative and polycentric) governance lower the analytic focus to actor interactions in collaborative, networked, or self-governed arrangements, we view the metagovernance concept's non-specificity with regard to actors and interactions as an advantage in enabling the full variety of 'governance of governance' activities to come into view.

Among the approaches to metagovernance proposed in the public administration literature, we adopt - and abridge for use here - the framework proposed by Stephen Bell and Andrew Hindmoor (2009). Bell and Hindmoor's 'SERDAL' evaluative framework is useful because, unlike other conceptions of metagovernance (e.g. Fransen 2015; Derkx \& Glasbergen 
2014), it specifically identifies key operational components of metagovernance: steering, effectiveness, resources, democracy, accountability, and legitimacy (see Bell and Hindmoor 2009). This approach makes metagovernance more readily applicable to empirical cases of governance via an analysis of exactly how, and the degree to which, each scheme exhibits key metagovernance components, in contrast to the broad conceptualisations found in the existing literature (e.g. Glasbergen 2011; Derkx 2013; Derkx \& Glasbergen 2014; Fransen 2015). A further advantage of the SERDAL framework it that it does not seek to locate the performance of metagovernance soley with organisations external to sectoral governance schemes (e.g. Fransen 2015). Consequently, the application of the SERDAL lens provides greater clarity about the systems and processes that help sustain, and in some cases compromise, the fair trade and sustainable forestry schemes.

Due to space constraints, a complete analysis of how each scheme performs against all elements of the Bell and Hindmoor framework is not feasible. We thus limit our analysis to highlighting three components of the framework: steering, effectiveness, and accountability. We concentrate on these three because we consider that 'steering' - as a foundational activity in the process of metagoverning - helps reveal how and why each scheme has evolved to scaleup their operations to permit global coverage and the key actors responsible; 'effectiveness' allows us to examine the development of the certification processes underpinning these schemes and how they operate; and 'accountability' sheds light on how governance mechanisms in each scheme have consolidated to promote due process and fairness. A comparative summary of the main ways in which the two schemes are metagoverned in regard to all six functions is presented in Table 1.

The methodological rationale for the case selection of these two 'most similar' cases (see Seawright and Gerring 2008) is that both the fair trade and sustainable forestry schemes are well-established exemplars of the global private governance phenomenon (see for example 
Renard 2003; Cashore et al. 2004; Espach 2009; Jaffee \& Howard 2010; Gulbrandsen 2010; Gale \& Haward 2011; Granville \& Dine 2013; Maguire 2013; Anderson 2015; Raynolds \& Bennett 2016; Jaffee \& Howard 2016). However, the schemes do represent different private governance trajectories: Fairtrade International emerged to bring coherence to a sector with a large number of existing national initiatives while the Forest Stewardship Council (FSC) formed to pre-empt the proliferation of national forestry certification schemes. Another difference is that FSC is a sector-specific certification scheme focused on forest products whereas Fairtrade International is trans-sectoral. Despite their contrasing trajectories and foci, we show that both schemes are metagoverned in similar ways. In undertaking the comparison, we draw on the extensive literature on Fairtrade International and the FSC, the business, government, and civil society literature on the various schemes, as well as our own longstanding engagement with each system.

The article is structured as follows: following this introduction, we explain in more detail what 'global private governance' entails and provide a brief summary of the fair trade and FSC certification schemes. We then provide an overview of the metagovernance concept, including the Bell and Hindmoor (2009) metagovernance framework. Section four subjects each scheme to an abridged application of Bell and Hindmoor's SERDAL metagovernance framework (2009) and the following discussion outlines what we learn from this applicaton via a comparison of the two schemes. A major finding is that global private governance schemes are not hierarchically metagoverned by single organisations but rather they are collectively metagoverned by several organisational bodies both inside and external to each scheme. The conclusion points to the relevance and utility of the metagovernance concept for analysis of diverse governance arrangements. It also suggests the need for further comparative metagovernance research on global private governance schemes to shed light on the strengths, 
weaknesses, and sustainability of their varying, heterarchical governing structures, processes, and operations.

\section{Global private governance}

Global private governance is a transnational voluntary form of governance that involves the development and use of standards, codes of conduct, certifications, and labels by business and civil society groups. Its purpose is to promote production and consumption behaviours that align with a prescribed set of social and environmental values. Other terms used to denote this category of governance include non-state market-driven governance, transnational private regulation, private standard-setting, voluntary consensus standard-setting, and transnational business governance (see Cutler et al. 1999; Cashore et al. 2004; Pattberg 2008; Bell and Hindmoor 2009; Green 2014; Fransen 2015; Eberlein et al. 2014). Among the chief global private governance organizations are Fairtrade International, FSC, International Federation of Organic Agriculture Movements, Marine Stewardship Council, Responsible Care, and UTZ Certified. While tailoring themselves to their sectoral requirements, today these organizations must also consider, shape, and respond to an established and well-accepted institutional architecture for global private governance. This encompasses the International Social and Environmental Accreditation and Labelling (ISEAL) Alliance, which sets meta-standards for the development of social and environmental standards organizations; to Accreditation Services International (ASI), which oversees the accreditation of certifying bodies (CBs) responsible for carrying out conformity assessments; and to the International Organization for Standardization (ISO), which governs the development of official national standards. Global private governance is thus a dense field featuring numerous issue-specific governance systems with complex relationships to other non-state and international organizations. Given their multi-layered complexity, global private governance schemes are good candidates for testing 
the analytical merits of the metagovernance concept. In particular, the aim of metagoverance analysis should be to decipher and analyse the key roles of the main actors, processes, and mechanisms that facilitate the operation of these schemes.

The schemes examined in this article, fair trade and sustainable forestry, are exemplars of the global private governance phenomenon. To illustrate in brief, the fair trade scheme is a certification and labelling arrangement that promotes improved working conditions and terms of trade for farmers and workers in developing countries. Though the scheme originated in the 1940s among third world development activists in the United States and Europe, today it is governed by an array of global fair trade organizations including Fairtrade International, World Fair Trade Organisation and FLOCERT (the certification body for Fairtrade International). The organizations serve as intermediaries between developing country producers of fair trade products and developed country consumers willing to pay a premium for fair trade labelled products, notably coffee, cocoa, and handicrafts among other product categories. Through the setting of fair trade standards, the scheme is said to offer an alternative trading arrangement that endeavours to pay producers a fair wage, promote environmentally sustainable production processes, and reduce the diversion of producers' income to global commodity chain intermediaries. Figure 1 sets out the basic organizational structure and relationships that comprise the fair trade system.

\section{Figure 1 to appear about here}

The FSC scheme emerged in the 1990s in a context of increased evidence of tropical deforestation and the limited effectiveness of international initiatives such as the International Tropical Timber Organization and the Tropical Timber Action Plan to halt it (Humphreys 
1996; Gale 1998). In late 1990, the Rainforest Alliance announced its SmartWood certification program, which had just certified the Indonesian state-owned forest Perum Perhutani as 'well-managed tropical woods' (Synnott 2005). With other organizations like Sustainable Certification Systems and Sustainable Forestry Institute declaring intentions to develop their own proprietary schemes, concern grew over a potential for a 'race to the bottom' in standards. Determined to secure a high-level international standard, civil society groups and businesses established a Certification Working Group in late 1990 and negotiated the parameters of an approach over a two-year period. This culminated in FSC's Inaugural Assembly, which was held in Toronto, Canada in October 1993. FSC established Accreditation Services International (ASI) in 2006 as an independent organization responsible for accrediting certification bodies. Along with Fairtrade International, FSC is a founding member of the ISEAL Alliance. Figure 2 provides a diagrammatic overview of the FSC system depicting the key organizations and relationships.

\section{Figure 2 to appear about here}

\section{Metagovernance}

Metagovernance is a relatively new concept in the field of politics and policy that refers to the management of governance processes that involve multiple participants and/or components. It has been expressed as "governing at a distance" (Rose \& Miller 1992, 173), governance "once removed" (Jayasuriya 2003, 5), "the regulation of self-regulation" (Sørensen 2006, 98), the "governance of network governance" (Torfing et al. 2012, 122) and "a means by which to

produce some degree of coordinated governance, by designing and managing sound combinations of hierarchical, market and network governance, to achieve the best possible 
outcomes" (Meutelman 2018, 15). The purpose of metagovernance is to 'glue' together the governance contributions of multiple actors to forge effective governance systems. As Torfing et al. $(2012,122)$ explain, metagovernance "involves deliberate attempts to facilitate, manage, and direct more or less self-regulating processes of interactive governance without reverting to traditional statist styles of government in terms of bureaucratic rule making and imperative command". Taken a step further, Eva Sørensen $(2006,102)$ argues that "metagovernance represents an alternative form of governing that differs from sovereign rule in that it is not based on direct and detailed top-down control but on a plurality of indirect ways of influencing or coordinating the actions of self-governing actors". Thus far, metagovernance discussions have mostly taken place in the context of domestic debates about the proliferation of policy networks and 'interactive governance' as contemporary modes of governance, the adapting role of the nation-state in an era of post-new public management, and the increasing demand for partnerships and community input into policy-making (Osborne \& Gaebler 1992; Pollitt \& Bouckaert 2004; Bell \& Park 2006; Bevir \& Rhodes 2010; Torfing et al. 2012).

A number of scholars have attempted to identify and characterise the strategies and components of metagovernance (see Sorensen 2006; Bevir 2009). In this vein, Bell and Hindmoor (2009) state that metagovernance involves the performance of six key SERDAL functions. Steering involves setting the rules of the game, selecting and coordinating the contributing actors, and achieving coherence in the governance arrangements utilised. Ensuring effectiveness concerns the setting of goals, targets and evaluative criteria in order to monitor the performance of governing actors, intervening when necessary. The resources provided by metagovernors may include leadership and authority, finance and administration, policy expertise, information, and legislation. Metagovernors may provide democracy by deciding overall priorities and goals, devolving authority and encouraging broad participation, thereby increasing opportunities for meaningful deliberation and representativeness. Safeguarding 
accountability involves delineating responsibilities, responsiveness and transparency, and holding other governance participants to account (see also Mashaw 2006; May 2007). At a domestic level, accountability mechanisms include legislatures, the media and citizens/electorate. Processes and outcomes that are seen as fair are more likely to be seen as legitimate. Legitimacy, the sixth metagovernance function, is said to be achieved as a byproduct of the successful delivery of the other metagovernance functions (Bell \& Hindmoor 2009). Together, the performance of these six roles constitutes a useful guide, and evaluative tool, for metagovernors in undertaking this important activity.

Recent scholarly work has looked to broaden understandings of the metagovernance concept beyond the domestic level of politics. As Eva Sørensen explains,

governance theorists tend to agree that metagovernance is exercised not only by state actors but also by various networks of public and private actors and a whole range of supranational, regional, and local levels in the formal political system. In fact, metagovernance can potentially be exercised by any resourceful actor - public or private. All it takes is resources and a desire to influence activities performed by self-governing actors (2006, 102-3).

In this regard, a small literature explicitly applying the concept of metagovernance to global private governance has emerged since 2011 (see Glasbergen 2011; Derkx 2013; Derkx \& Glasbergen 2014; Verbruggen \& Havinga 2014; Murphy 2015; Fransen 2015). In Derkx and Glasbergen's analysis, metagovernance is conceptualised as emerging functionally to overcome the "orchestration deficit" consequent on the proliferation of private global governance schemes and bring "more coherence in the governance of an issue area". In their own words, Derkx and Glasbergen $(2014,42)$ state that:

Transcending the governance activities of individual private and public actors in an issue field, meta-governance looks at the complementarity of these governing activities and aims to give them a logical place related to each other in an encompassing intervention strategy. Placed in the recognition of networks of governing actors and the governance of such 
networks [...] the meta-governance concept thus draws attention to the management of plurality with the aim of bringing more coherence in the governance of an issue area.

In their analysis of fair labour, sustainable tourism, organic certification, and of the ISEAL Alliance, Derkx and Glasbergen (2014) identify two metagovernance pathways that are used to overcome the problem of fragmentation. In the first, substantive pathway, network actors work towards a 'consensus standard' that sees at least a degree of convergence towards the underlying meaning of contested terms like 'fair labor', 'sustainable tourism' and 'organically produced'. In the second, procedural pathway, network actors converge towards agreement on best practices in standards' development. Given the difficulties that already institutionalised organizations have in compromising on their substantive commitments, they conclude that "most private meta-governance attempts are on the second pathway, which in terms of the cohesion realized is the weaker form of metagovernance" (Derkx \& Glasbergen 2014, 49).

Whereas Derkx and Glasbergen (2014) contend that metagovernance may help reduce standards' fragmentation and the orchestration deficit, Fransen (2015) argues that the same dynamics underlying the emergence of competing standards also underlie the emergence of competing metagovernance arrangements. Taking a 'political' rather than a problem-solving or sociological-ideational approach, Fransen reviews competing metagovernance institutions in the field of sustainable agriculture with a focus on coffee and cocoa. Arguing that large company brands like Unilever, Kraft, and Walmart see certification and labelling as contributing to supply chain risk management, he concludes:

Meta-governance initiatives are developed by actors with different positions in production chains and different priorities in PSO [Private Standard Organization] coordination, and therefore also different approaches within modes of metagovernance, which they seek to govern among a coalition of likeminded actors" (2015, $314)$. 
In short, Fransen contends that private metagovernance will not resolve the global standards fragmentation problem because the same interests that generate different global standards also underpin the dynamics of global metagovernance.

Overall, the literature that applies the metagovernance concept to global private standards demonstrates that such standards are being metagoverned by non-state actors. It has further identified the use of several metagovernance strategies that include forming dedicated metagovernance institutions and engaging in network design, market design, and trust building. The extant literature assumes that metagovernance must be performed by a 'higher' level organization located outside sectoral governance networks and places a great deal of emphasis on the role of the ISEAL Alliance (Fransen 2015). Finally, while analysts have identified how ISEAL metagoverns, the strategies it uses are conceptualised quite broadly, which suggests merit in employing the more systematic SERDAL framework to analyse specific metagovernance strategies. Below, we turn to our abridged application of the SERDAL framework to the cases of fair trade and sustainable forest products.

\section{The global metagovernance of fair trade and forest products}

Metagovernance: steering

According to Bell and Hindmoor (2009), the metagovernance function of steering involves defining the parameters of the governed activity by establishing the 'rules of the game' as well as enlisting and coordinating the contributing governance actors. For the fair trade scheme, Fairtrade International, the World Fair Trade Organization (WFTO), ISEAL Alliance, and ISO simultaneously contribute to the system's coherence and 'rules of the game'. They do so via the provision of specific fair trade standards for product certification (Fairtrade International), guiding principles and code of practice for fair trade organizations (WFTO), a fair trade charter 
(WFTO and Fairtrade International), and meta-standards (ISEAL Alliance and ISO). Additionally, Fairtrade International and WFTO coordinate the inputs of the contributing actors according to their role in fair trade supply chains and, by serving as peak 'umbrella' organizations that unite the participating organizations, represent the scheme as a whole and cohere with global meta-standards bodies. We now examine these roles in more detail below.

A global overarching organisation to steer national and regional fair trade efforts was established in 1989 in the form of the International Federation for Alternative Trade (IFAT). IFAT was envisaged as a loose umbrella network comprising 150 fair trade groups in 47 countries. While IFAT provided an initial global forum for diverse fair trade groups, by the mid-1990s, a group of European fair trade civil society organizations (CSOs) began pushing for further formalisation and coherence for the scheme. Consequently, in 1997, a second global-level body, the Fairtrade Labelling Organizations International (FLO) was set up for the scheme in order to promote greater consistency in fair trade certification standards, criteria, and practices. The govenance of the scheme underwent further evolution in 2004 when FLO was split into two independent organisations in order to separate standard-setting from assessment and verification. FLO thus transformed into Fairtrade International, which sets Fairtrade standards and provides producer support, and FLOCERT, which inspects and certifies producer organizations and audits traders. ${ }^{1}$ In a further adaption in the governance of the scheme, the 1989-created organisation, IFAT, was renewed and rebranded in 2008 as WFTO, a global network of organizations representing all supply chain actors from producers to retailers with a mandate to certify fair trade organizations. WFTO currently represents over 370 organizations including producer cooperatives, marketing corporations, importers, retailers and whole fair trade national and regional networks, and five regional branches (WFTO 2014). 
Fairtrade International and WFTO play key global steering roles in fair trade activity supplemented by other global standards bodies, notably, ISEAL Alliance and the ISO. Fairtrade International provides the overall steering and coordination of the scheme, a crucial foundational task being to establish 'common principles' and develop the international fair trade standards that underpin the entire regime. Fairtrade International's four common principles require members to foster social and economic development, environmental protection and prohibit forced labor and child labor; additional principles apply to small producers and hired labor (Fairtrade International 2011a). To steer the scheme, Fairtrade International's Standards Unit and Standards Committee have thus far developed standards for small producers, hired labor, contract production, traders, climate change, and textiles as well as numerous product specific standards that were last revised in 2011 (Fairtrade International $2011 b) .^{2}$

The role of Fairtrade International in standards' development is supported by the WFTO. The WFTO's 10 principles of fair trade and code of practice, aimed at the entire fair trade supply chain, enable it to steer and monitor that aspect of fair trade that certifies fair trade organizations rather than fair trade products. WFTO's code of practice (approved in 1995) and principles (last revised in 2013) relate to the social, economic, and environmental wellbeing of producers, transparency and accountability, womens' empowerment, labor rights, and capacity building (WFTO 2014a, 2014b). ${ }^{3}$ In 2009, WFTO and Fairtrade International joined forces to provide a single international reference point for fair trade through the adoption of a charter of principles. The charter sets out a definition of fair trade, explains the fair trade principles, and outlines the two main avenues offered by each organization for certifying fair trade activity (WFTO 2014c). ${ }^{4}$

As a global metastandards organization, the ISEAL Alliance helps Fairtrade International and WFTO steer fair trade activity via the standards setting process. During the 
formative period of private global governance in the 1990s, Fairtrade International (together with other private governance organizations) formed the ISEAL Alliance, a private governance umbrella organization (Laconto \& Fouilleux 2014, 170). WFTO is an associate member of ISEAL Alliance (since 2011) while Fairtrade International is a full member and is compliant with the ISEAL Standard-Setting Code and ISEAL Impacts Code.

In guiding its members to develop robust standards across various sectors, the ISEAL Alliance has developed several Codes of Good Practice related to the process of setting standards, measuring impacts, and performance assurance audits. For example, in 2014 it completed a revision of its Code of Good Practice for Setting Social and Environmental Standards, which is based on its recently negotiated ten principles of credibility: sustainability, improvement, relevance, rigour, engagement, impartiality, transparency, accessibility, truthfulness, and efficiency (ISEAL Alliance 2014). In essence, the ISEAL Alliance provides standards for the development of standards, or meta-standards, for accrediting 'responsible' production. It thus performs a vital steering role through setting and cohering the broader 'rules of the game' of global private governance.

Yet another meta-standards organization active in metagoverning fair trade albeit in a 'hands-off' manner, is the ISO through its standards and processes for certification (see Heires 2008). FLOCERT, which certifies and audits fair trade, follows the ISO standards for certification bodies and in 2007, FLOCERT became the first social certification body to obtain ISO accreditation (then ISO/IEC Guide 65:1996) for its fair trade certification services. Further, in 2015, FLOCERT received accreditation against the revised standard (ISO/IEC 17065), which among other changes, further strengthens the impartiality of processes. ISO's indirect steering of fair trade certification situate it alongside the ISEAL Alliance as a global governance body that shapes sector specific activity through the provision of general advice 
about standards development. In this respect, both ISEAL Alliance and ISO qualify as metagovernors.

Unlike Fairtrade, the FSC emerged to pre-empt the establishment of diverse and competing business and civil society forest certification schemes and to steer emerging initiatives towards a single, coherent approach. As noted, FSC was only partly successful in this effort as its establishment led to competitor schemes set up by national forestry associations who objected to FSC's governance arrangements and 'niche' market focus. Today the market for certified forest products is split between FSC and the umbrella competitor scheme, the Programme for the Endorsement of Forestry Certification (PEFC) and a company seeking certification can opt for one, the other, or both depending on its geographic location, market structure, and management orientation. In aiming to certify and label products from responsibly managed forests, FSC first had to determine the parameters of the system it wished to govern. Critical decisions debated early in the Certification Working Group were whether to certify only tropical forests or include temperate and boreal forests; whether to certify natural and semi-natural forests only or include plantations; whether to focus on forest and environmental management only or to include social, community and indigenous peoples' issues; and whether to establish a 'step-wise' or 'in-out' scheme. Decisions on these and other matters are reflected in early drafts of FSC's principles and criteria (P\&C), which collectively establish the meaning of 'responsibly managed' forests. ${ }^{5}$ The final draft of FSC's P\&C document tabled at the 1993 Founding Assembly was composed of nine principles and associated criteria; a subsequent tenth principle on plantations was added in 1996. In essence, FSC's P\&C document is the basic framework upon which the entire certification and labeling system is built. It sets the 'rules of the game' for the private global governance of forest product certification that other governing actors in its network must adhere to in order to be seen as legitimate governing participants and to be able to use the organization's logo. In 2012, a new set of P\&Cs was developed which is 
being coupled with a set of international generic indicators (IGIs) to further harmonise national standards.

As with Fairtrade International, FSC was a co-founder of ISEAL Alliance and also observes the requirements of several ISO standards including ISO/IEC 17065 with regard to conformity assessment. As a full member of the ISEAL Alliance, FSC shapes, and is shaped by, its evolving credibility principles and codes of conduct with regard to standard setting, assurance and impact assessment good practice guidelines. FSC's longstanding experience in multi-stakeholder governance has not only shaped the structure of many ISEAL Alliance members (including the Marine Stewardship Council, Roundtable for Sustainable Soy and Roundtable for Sustainable Palm Oil) but FSC's own multi-stakeholder procedures for standards' development are reflected in various ISEAL Alliance codes of best practice. FSC's approach to certification audits has also been steered by ISO, as ISO 17065 specifies that standard setting, certification audits, and auditor accreditation should be carried out by independent bodies. While FSC undertook both standard setting and auditor accreditation inhouse at the outset, since 2006 it has outsourced the accreditation function to a new, independent organization, ASI, to conform to ISO requirements.

\section{Metagovernance: effectiveness}

The metagovernance function of effectiveness differs from steering in that it involves the development of specific goals, targets, and evaluative criteria for monitoring the governing actors' performance and intervening if required. Within fair trade, activities to ensure scheme effectiveness are undertaken by three organizations: Fairtrade International, FLOCERT and WFTO. Fairtrade International is tasked with developing clear criteria and practices for the conduct of certification to ensure that the conditions of production and trade of certified 
products occur in accordance with fair trade standards (Fairtrade International 2011a). Fairtrade International has developed a Fairtrade Assurance Program that details the process of certification to ensure it is independent and consistent. A multi-stakeholder Oversight Committee consisting of members appointed by the organization's Standards Committee is responsible for managing the Assurance Program. In 2015, Fairtrade International implemented its oversight procedures and requirements for licensing bodies and assurance providers and appointed an Assurance Manager to ensure conformity with the new guidelines (Fairtrade International 2015, 5).

Since 2004, FLOCERT has played a vital effectiveness role by serving as the global certification arm of the fair trade system, ensuring that Fairtrade International's standards are upheld by participating organizations (FLOCERT 2015. FLOCERT was established as a private limited company to inspect and audit producers and traders to ensure compliance with the fair trade standards and that producers invest the benefits received back into the fair trade system. FLOCERT currently operates in more than 115 countries, has around 90 employees, more than 100 auditors, and over 3,300 customers across the world, ranging from small producers to large global retailers (FLOCERT 2015).

Yet another aspect of ensuring effectiveness in the fair trade scheme is the certification of fair trade producer organizations. Since 2013, WFTO has fulfilled this role, presenting itself as a global network of organizations representing the totality of supply chains from producers to retailers. WFTO implements its certification via its own 'guarantee system' based on the criteria of credibility, sustainability, and robustness (WFTO 2014). Organizations that meet the requirements may place the WFTO label on their products to signify their status.

Securing effectiveness in the FSC network is the responsibility of FSC, ASI and accredited certification bodies. It has been argued that CBs experience a conflict of interest because their business model requires them to charge fees for conducting audits. To ensure that 
CBs act independently and in accordance with requirements, FSC has progressively sought to curb their discretion regarding how the $\mathrm{P} \& \mathrm{Cs}$ are interpreted, the composition of audit teams, and their consultancy activities. Until recently, FSC permitted CBs to utilise their own in-house 'generic' forest certification standards in countries lacking a national standard, an arrangement that resulted in different $\mathrm{CBs}$ employing different indicators, leading to significant variation in outcomes and many stakeholder grievances. To more effectively implement its scheme, FSC recently negotiated the IGIs, which CBs must uniformly employ. Furthermore, FSC will require countries to revise their national standards in accordance with the IGIs during the next regular revision cycle.

ASI is tasked with accrediting CBs and overseeing their effectiveness by ensuring they meet the requirements of the FSC accreditation standard. ${ }^{6}$ The standard sets out what is expected of a CB, covering type of activity; impartiality and consulting; and the structure and qualifications of audit teams. ASI assesses applications from candidate CBs against these standards based on documentation and field visits; in the event of complaints, it may issue noncomformity notices, suspend, or ultimately cancel a CB's licence.

\section{Metagovernance: accountability}

The metagovernance function of accountability concerns transparency, the delegation of responsibilities, and responsiveness to stakeholders. Accountability within the fair trade scheme is upheld by Fairtrade International, FLOCERT and WFTO. The 2004 decision to separate the standard-setting side of Fairtrade International from the assessment and verification processes is demonstrative of this concern. The restructure was a clear metagovernance exercise in that it delineated responsibilities and aimed to improve the scheme's robustness. At FLOCERT, a Supervisory Board consisting of at least five members 
drawn from a range of stakeholders' groups and experts is accountable to Fairtrade International. The Board oversees FLOCERT's finances, appoints the managing director, and presides over rules of procedure and the organizational activities requiring General Meeting approval. In other FLOCERT related accountability developments, FLOCERT was accredited as a 'social enterprise' in 2015 by the Social Enterprise Mark Community Interest Company and possesses ISO 17065 certification, which is verified by an independent third party. WFTO possesses the most advanced accountability mechanism in the form of the Fair Trade Accountability Watch tool. It is a participatory mechanism that allows members of the public to report possible fair trade compliance problems by submitting an online form. This development forms part of the WFTO's broader 'guarantee system' aimed at boosting the compliance of fair trade organizations with WFTO's standards.

The metagovernance function of accountability in the FSC is evident in the evolution of processes for accrediting CBs. Unlike Fairtrade International, FSC adopted an independent, third-party approach to certifying compliance and CBs are independent for-profit and not-forprofit organizations that audit forestry operations to the FSC standard. Given that CBs are paid by forest companies to undertake audits, they must be accredited and subjected to ongoing monitoring in order to avoid conflicts of interest. In the first decade of operation, FSC accredited CBs via an in-house Accreditation Business Unit. However, given the conflict of interest between developing sustainability standards for forestry and accrediting CBs to audit those standards, the arrangement did not conform to international best practice as set out in ISO/IEC Guide 65/17065. Consequently, in 2006 FSC set up ASI as an independent agency to accredit CBs.

To meet its mandate, ASI accredits CBs to audit company performance against the FSC's standards. ${ }^{7}$ In addition to periodic accreditation audits, ASI has the option of producing summary reports of an investigation, suspending, or terminating accreditation. As with other 
certifications within the FSC, an ASI assessment of a CB can identify minor or major "nonconformities'. While each require correction, minor non-conformities that are not addressed within a 'reasonable' time frame can become major non-conformities, leading to greater censure. FSC has also evolved a sophisticated Disputes Resolution System that varies depending on the nature of the grievance. ${ }^{8}$ Stakeholders objecting to an aspect of a CB's certification lodge a complaint with the company. If not satisfied, they can escalate the complaint to the CB and, if concerns remain, to ASI and ultimately the FSC. Defendants also have rights of appeal, which may be heard by an independent Appeals Panel.

FSC also has the option of invoking its 'Policy of Association', which sets out the conditions under which it can disassociate from companies flouting its principles. One recent example is FSC's disassociation from the actions of the German-based Danzer Group of forest companies following an inquiry into a subsidiary in the Democratic Republic of Congo that was alleged to have paid local militia to intimidate community members (FSC 2013). The accountability aspect of metagovernance is therefore a crucial task as it guards against conflicts of interest and non-compliant participants. In particular, the separation of the FSC, ASI, and the CBs, as well as the separation of WFTO, Fairtrade International, and FLOCERT helps strengthen these governance systems.

Summarising the findings of our comparative analysis of steering, effectiveness, and accountability, we note the following. Steering is undertaken by a few high-level organisations, these emerging as a result of a functional division of labour as private governance systems' evolve. Thus, IFAT was overtaken by FLO after 1997 with FLO subsequently splitting into Fairtrade International and FLOCERT in 2004 and IFAT being rebranded as WFTO in 2008. FSC spawned ASI after 2006 and both Fairtrade International and FSC combined with other standard setting organizations to form the ISEAL Alliance in the same year to enhance the steering of standards development. The greater functional specificity of organisations within a 
private governance system has enabled them to more effectively perform specific roles leading to enhanced implementation. Thus, Fairtrade International developed its fairtrade assurance program to better ensure consistency across the audit process; and FSC proliferated standards beyond forest certification for chain of custody and controlled wood to eliminate potential loopholes. Finally, to secure the accountability of diverse actors in the system to each other and the system overall, each scheme has elaborated horizontal and vertical auditing and dispute resolution arrangements as evidenced in WFTO's Fair Trade Watch scheme and FSC's Policy of Association.

\section{Discussion}

Our systematic analysis of two prominent global private governance schemes in the areas of fair trade and forest product certification demonstrate that global metagovernance is being performed not by single organsations hierachically, but by a collective of global level organisations heterachically. We thus highlight three main conclusions regarding the provision of metagovernance supporting global private governance: (1) global metagovernance is demand-driven; (2) global metagovernance is best characterised as a heterachic, rather than hierarchic, activity; and (3) the global meta-standards bodies, ISEAL Alliance and ISO, significantly contribute to the metagovernance function of steering.

\section{(1) The demand for global metagovernance}

One of the most striking differences between the metagovernance literature and the metagovernance of global private governance discussed here is in regard to the demand for metagovernance. At the national level of governance, metagovernance is portrayed a top-down affair whereby metagovernors seek to supply metagovernance by exerting control through 
setting the 'rules of the game', establishing policy objectives, selecting and directing participants, and providing resources. But in global private governance, the opposite dynamic is evident. Confirming the insights of Verbruggen and Havinga (2014), organizations that privately govern various issue areas are seeking additional sources of authority and legitimacy as a 'stamp of approval' for their activities, often in an effort to connect with parallel civil society activities in national and regional contexts and existing global governance standards. FSC's move to constitute its own accreditation and auditing agency, ASI, illustrates this dynamic, as does the establishment of the ISEAL Alliance by Fairtrade International and FSC as a forum for developing meta-standards for best-practice standards' setting.

Furthermore, the literature on metagovernance in domestic arenas implies a level of control and coercion that is not readily transferrable to the global level. A fundamental characteristic of global governance is the absence of overarching authority, or global government, meaning that the creation of a metagoverning body is the subject of negotiation among multiple actors and therefore must occur via mutually agreeable arrangements. Once established however, new actors seeking to join a metagoverned system must adhere to the already negotiated conditions if they are to be recognised by it, utilise a label, or make a claim against a standard that will enhance its reputation. Metagovernance in global private governance is therefore best understood as a demand-driven, bottom-up process; the 'control' aspect that features in national level metagovernance is less prominent. Instead, global metagovernance centrally involves self-governing actors seeking coherence and legitimacy for their activities as they evolve in the light of experience, a search that may ultimately reduce the complexity of governing at the global level through the institutionalisation and convergence of known and recognisable global standards. 
Our two cases reveal how organizations in private global governance structure and restructure their relationships to forge effective governing systems that do not rely upon hierarchy and formal authority. Instead, the relationships between national organizations, confederations of national organizations, global civil society groups, and multi-stakeholder groups that characterise the fair trade and FSC networks are better characterised as heterarchic. This is because the organizational relationships are not based upon a 'command and control' mode but instead the metagoverning organizations for each scheme collaborate and liaise to develop a common set of principles and standards, certification and labelling arrangements, and oversight mechanisms.

The heterarchical nature of global private metagovernance is evident in our two case studies where fair trade and FSC certification are each metagoverned by several organizations. Fairtrade International, WFTO, FLOCERT, ISEAL Alliance, and ISO are the metagovernors of the fair trade certification scheme while FSC, ASI, ISEAL Alliance, and ISO metagovern responsibly managed forest certification. ISO may be considered 'external' to both schemes but it exercises an important steering role in that its ISO/IEC Guide 65/17065 standard requires the separation of standard-setting from the auditing and accreditation functions, which was achieved via the separation of Fairtrade International and FLOCERT and by FSC's establishment of ASI. Indeed, FLOCERT and ASI may be considered 'internal' to their schemes, crucially contributing to the metagovernance functions of effectiveness and accountability. The balance achieved between promoting organizational collaboration yet ensuring that certification and audits are sufficiently independent to avoid conflicts of interest help promote the legitimacy of the governing arrangements in their entirety.

(3) The role of global metastandards organizations: ISEAL Alliance and ISO 
Our cases also demonstrate that both ISEAL Alliance and ISO exercise a significant steering function for affiliated sectoral organizations and thus offer an additional level of robust, independent yet democratic governance that boosts sectoral scheme reputation and legitimacy. ISEAL Alliance guides each scheme towards 'best practice' standards development based on its Code of Good Practice for Setting of Social and Environmental Standards. Implicit in the Code is a vision of democracy based on the implementation of proper processes. For example, while the Code is not prescriptive with regard to standards development structures (it does not require members to adopt a tri-chamber model for example) it does require the identification and incorporation of stakeholders into the standards development process; the adoption of transparent mechanisms for assessing complaints; and the use of performance-based metrics that enhance sustainability (ISEAL Alliance 2014, 18). In addition to the steering and democratic functions, the ISEAL Alliance also provides resources to its members, particularly research, where it reports on the latest studies to members and contracts research in specific areas of interest.

ISO has played an important metagovernance role too with regard to the protocols and structures adopted by the fair trade organizations and FSC to certification and labelling. Whereas both schemes originally operated in-house auditing and accreditation divisions, in response to the provisions of ISO/IEC Guide 65/17065 (which sets out guidelines for standards development, auditing and accreditation), both were devolved in the early 2000s to separate organizational entities: FLOCERT and ASI. Interestingly, however, the degree of devolution is not entirely complete with, for example, ASI remaining a 100 percent owned FSC subsidiary. The reason for maintaining this relationship is that FSC, through ASI, desires a higher degree of control than that provided by the ISO system over how CBs implement standards to secure scheme effectiveness (Wenban-Smith 2007). 


\section{Conclusion}

In this article, we argue that the concept of metagovernance offers important insights into the evolution of global private governance, and that it is particularly helpful as both a conceptual and analytical tool for unravelling the organizational complexities that have emerged in the forest and fair trade certification governance systems. When the fair trade organisations and the FSC were formed in the 1990s, they were relatively isolated and perhaps somewhat idealistic initiatives pioneering the idea of global governance via standards backed by certification and labelling systems in niche markets. As they gained operational experience, adaptations were required to address existing and emerging concerns, leading to organisational splits on the one hand and to the creation of new organisations on the other, that then required forms of heterarchy to manage the resulting organisational 'ecosystem'. Following two decades of experience, these schemes - now joined by many others - have not only 'mainstreamed' their operations and exerted effects on international markets, they have also joined forces to bolster their legitimacy in a world otherwise dominated by powerful states and business actors, many of which are suspicious of civil society organisations' motivations and often hostile to their governance agendas.

One notable arena of conflict on the horizon is the relationship between global private governance schemes and the global trade system that may yet prompt more determined action by states and intergovernmental organizations. Some governments are concerned that the FSC and fair trade CSOs preside over 'trade restrictive' and 'discriminative' standards that are in contravention of the spirit, if not the letter, of World Trade Organization rules. Notably, there are provisions in the Technical Barriers to Trade Agreement with regard to best-practice standards development that seek to regulate the development and deployment of official standards. To date, these have not been invoked to discipline private governance, but as sectoral standards and certification schemes proliferate and increasingly have regulatory effects, and as 
competing metagovernance systems in the form of the PEFC/ISO/IAF and FSC/ISEAL Alliance/ASI systems emerge, some governments may seek to extend TBT provisions to private standards. Marx and Wouters $(2014,19-20)$ speculate on whether this could be a role for the newly formed United Nations Forum on Sustainability Standards although it is not currently envisaged in the Organization's work program.

Ultimately, our analysis demonstrates the need for more research on the metagovernance of global private governance. We recognise the limitations of our small, qualitative comparative case study and the need to replicate the findings across the larger number of global private governance arrangements that include organic agriculture, seafood (wild and farmed), soy and palm oil, as well as ISO itself. A larger comparative study may assist in determining the degree to which metagovernance through heterarchy is a response to the practical challenges raised by scheme implementation experience; and contribute to more precisely defining the boundaries between 'network governance' and 'metagovernance'. On the latter point, one of the difficulties with the Bell and Hindmoor framework is that the large number of diverse functions blurs the line about where governance ends and metagovernance begins. The solution to this difficulty, equating metagovernance with 'external' organizations such as ISEAL Alliance or ISO as Derkx and Glasbergen (2014) as well as Fransen (2015) do, is unsatisfactory however. This approach excludes intra-network actors from exercising a metagovernance function by fiat, potentially distorting our understanding of the governance relationships. Moreover, it is not evident that the most studied metagovernor in this literature, ISEAL Alliance, is actually external to the actors it is metagoverning since it is a membership organization composed of network members. And while the ISO appears as an external actor to the fair trade and FSC schemes and thus evidently exercises a metagovernance role with regard to standard setting, auditing, and accreditation, ISO performs an identical role within its own network where it manages the development of product standards. It thus appears to be 
metagoverning the Fairtrade Alliance and FSC and governing its own ISO network actors which, while not logically impossible, is certainly provocative and worthy of further analysis.

\section{Author biographies}

Dr Hannah Murphy-Gregory is a Lecturer in the Politics and International Relations Program of the School of Social Sciences at the University of Tasmania, Australia. Her research focuses on civil society campaigning in the process of governance in Australia and globally in the areas of marine governance, tax justice, and labour standards. Dr Murphy-Gregory's research is published in a range of international outlets including Environmental Politics, Global Policy, and Review of International Political Economy. She is co-editor of Handbook of Research on NGOs (with Aynsley Kellow, Edward Elgar, 2018) and a co-author of Australian Politics in the Twenty-First Century (Cambridge Univeristy Press, 2018).

Dr Fred Gale is an Associate Professor in the Politics and International Relations Program of the School of Social Sciences at the University of Tasmania, Australia. His research focuses on rethinking the discipline of political economy from a sustainability perspective with a focus on state, international organisation, corporate and NGO governance arrangements. Dr Gale has published in a wide range of journals including Ecological Economics, Global Environmental Politics and Public Administration. His new book, The Political Economy of Sustainability (Edward Elgar, 2018), reconceptualises economic value from a sustainability perspective and outlines implications for collaborative governance required to realise it. 


\section{References}

Abbott, Kenneth and Duncan Snidal. 2009. "Strengthening International Regulation through Transmittal New Governance: Overcoming the Orchestration Deficit.” Vanderbilt Journal of Transnational Law 42: 501-578.

Anderson, Matthew. 2015. A History of Fair Trade in Contemporary Britain. London: Palgrave Macmillan.

Ansell, Chris and Alison Gash. 2008. "Collaborative Governance in Theory and Practice." Journal of Public Administration Research and Theory 18, 4: 543-571. Accessed on October 12, 2018. Available online at https://doi.org/10.1093/jopart/mum032

Bell, Stephen and Andrew Hindmoor. 2009. Rethinking Governance: The Centrality of the State in Modern Society. Cambridge, NY: Cambridge University Press.

Bell, Stephen and Alex Park. 2006. “The Problematic Metagovernance of Networks: Water Reform in New South Wales". Journal of Public Policy 26 (1): 63-83. Accessed on October 12, 2018. Available online at https://doi.org/10.1017/S0143814X06000432

Betsill, Michelle and Harriet Bulkeley. 2004. "Transnational Networks and Global Environmental Governance: The Cities for Climate Protection Program. International Studies Quarterly 48 (2): 471-493. Accessed on October 12, 2018. Available online at https://doi.org/10.1111/j.0020-8833.2004.00310.x

Bevir, Mark. 2009. Key Concepts in Governance. London: Sage Publications

Bevir, Mark. 2011. The Sage Handbook of Governance. London: Sage Publications.

Bevir, Mark and Rod Rhodes. 2010. The State as Cultural Practice. Oxford: Oxford University Press. 
Cashore, Benjamin, Graeme Auld and Deanna Newsom. 2004. Governing through Markets: Forest Certification and the Emergence of Non-State Authority. New Haven: Yale University Press.

Cutler, Claire, Virginia Haufler and Tony Porter. 1999. Private Authority and International Affairs. Albany, NY: SUNY.

Derkx, Boudewijn. 2013. Meta-governance in the Realm of Voluntary Sustainability Standards: Early Experiences and Their Implications. United Nations Forum on Sustainability Standards Discussion Papers, No. 1. UNCTAD/DITC/TED/2013/1. Accessed on July 30, 2016. Available online at http://unctad.org/en/PublicationsLibrary/ditcted2013d1_en.pdf

Derkx, Boudewijn and Pieter Glasbergen. 2014. "Elaborating Global Private Metagovernance: An Inventory in the Realm of Voluntary Sustainability Standards.” Global Environmental Change 27: 41-50. Accessed on October 12, 2018. Available online at https://doi.org/10.1016/j.gloenvcha.2014.04.016

Eberlein, Burkard, Kenneth W Abbott, Julia Black, Errol Meidinger, and Stepan Wood. 2014. “Transnational Business Governance Interactions: Conceptualization and Framework for Analysis." Regulation \& Governance 8, 1-21. Accessed on October 12, 2018. Available online at https://doi.org/10.1111/rego.12030

Espach, Ralph. 2009. Private Environmental Regimes in Developing Countries: Globally Sown, Locally Grown. Manchester: Palgrave Macmillan.

Fairtrade International. 2011a. Aims of Fairtrade standards. Accessed on June 18, 2015. Available online at http://www.fairtrade.net/aims-of-fairtrade-standards.html 
Fairtrade International. 2011b. Our Standards. Accessed July 29, 2016. Available online at http://www.fairtrade.net/standards/our-standards.html

Fairtrade International. 2011c. Who We Are. Accessed July 29, 2016. Available online at http://www.fairtrade.net/about-fairtrade/who-we-are.html

Fairtrade International. 2015. Fairtrade International Oversight Procedure. Accessed July 29, 2016. Available online at http://www.fairtrade.net/fileadmin/user_upload/content/2009/standards/documents/ ASSU_OversightProcedure_v1.0.pdf

FLOCERT. 2015. "About Us." Accessed on June 18, 2016. Available online at http://www.flocert.net/about-us/

Fransen, Luc. 2015. "The Politics of Meta-governance in Transnational Private Sustainability Governance.” Policy Sciences 48, 293-317. Accessed on October 12, 2018. Available online at https://doi.org/10.1007/s11077-015-9219-8

FSC. 2016. "FSC Facts \& Figures.” 6 June. Forest Stewardship Council, Bonn.

FSC. 2015a. "Forest Stewardship Council A.C., and Subsidiaries: Consolidated Financial Statements: Years Ended December 31, 2014 and 2013, with Report of Independent Auditors.” Forest Stewardship Council, Bonn.

FSC. 2015b. "FSC AC Members List." Accessed June 13, 2015. Available online at http://chportal.fsc.org/PublicMember Search

fsc-watch.com. 2016. "Jari Certificate Suspension: Why Was it Ever Certified in the First Place?" Accessed June 13, 2015. Available online at https://fscwatch.com/2015/12/22/jari-certificate-suspension-why-was-it-ever-certified-in-thefirst-place/ 
Gale Fred, and Marcus Haward. 2011. Global Commodity Governance: State Responses to Sustainable Forestry and Fisheries Certification. Palgrave Macmillan, Basingstoke, UK.

Gale, Fred. 1998. The Tropical Timber Trade Regime. Palgrave Macmillan, Basingstoke, UK.

Glasbergen, Pieter. 2011. "Mechanisms of Private Meta-governance: An Analysis of Global Private Governance for Sustainable Development." International Journal of Strategic Business Alliance 2, 189-206. Accessed on October 12, 2018. Available online at https://doi.org/10.1504/IJSBA.2011.040886

Granville, Brigitte and Janet Dine. 2013. The Processes and Practices of Fair Trade: Trust, Ethics and Governance. New York: Routledge.

Green, Jessica. 2014. Rethinking Private Authority: Agents and Entrepreneurs in Global Environmental Governance. Princeton, NJ: Princeton University Press.

Greenpeace, 2015. “The Forest Stewardship Council.” Accessed on July 29, 2016. Available online at http://www.greenpeace.org/international/en/campaigns/forests/solutions/alternatives-toforest-destruc/

Gulbrandsen, Lars H. 2010. Transnational Environmental Governance: The Emergence and Effects of the Certification of Forests and Fisheries. Edward Elgar, Cheltenham.

Heires, Marcel. 2008. “The International Organization for Standardization (ISO).” New Political Economy 13 (3): 357-367. Accessed on October 12, 2018. Available online at https://doi.org/10.1080/13563460802302693

ISEAL Alliance. 2014. “Standard-Setting Code.”Accessed on March 3, 2016. Available online at http://www.isealalliance.org/our-work/defining-credibility/codes-of-goodpractice/standard-setting-code 
Jaffee, Daniel, and Philip Howard. 2016. "Who's the Fairest of Them All? The Fractured Landscape of U.S. Fair Trade Certification.” Agriculture \& Human Values 33 (4), 813826. Accessed on October 12, 2018. Available online at https://doi.org/10.1007/s10460015-9663-2

Jaffee, Daniel and Philip Howard 2010. "Corporate Cooptation of Organic and Fair Trade Standards.” Agriculture \& Human Values 27 (4), 387-399. Accessed on October 12, 2018. Available online at https://doi.org/10.1007/s10460-009-9231-8

Jayasuriya, Kanishka. 2003. "Workfare for the Global Poor: Anti Politics and the New Governance.” Working Paper No. 98. Asia Research Centre, Murdoch University, September 2003.

Jessop, Bob. 2003. “Governance and Metagovernance: On Reflexivity, Requisite Variety, and Requisite Irony." Accessed on June 18, 2015. Available online at http://www.lancaster.ac.uk/sociology/research/publications/papers/jessop-governanceand-metagovernance.pdf

Laconto, Allison and Eve Fouilleux. 2014. "Politics of Private Regulation: ISEAL and the Shaping of Transnational Sustainability Governance.” Regulation \& Governance, 8 (2): 166-185. Accessed on October 12, 2018. Available online at https://doi.org/10.1111/rego.12028

Maguire, Rowena. 2013. Global Forest Governance. Cheltenham, UK: Edward Elgar.

Mashaw, Jerry. 2006. "Accountability and Institutional Design: Some Thoughts on the Grammar of Governance." In: Public Accountability: Designs, Dilemmas and Experiences, edited by Michael Dowdle, pp. 115-156. Cambridge University Press, Cambridge. 
Marx, Axel and Jan Wouters. 2014. Competition and Cooperation in the Market of Voluntary Sustainability Standards. UNFSS Discussion Paper 3, Leuven Centre for Global Governance Studies, KU Leuven, The Netherlands.

May, Peter. 2007. "Regulatory Regimes and Accountability". Regulation \& Governance 1 (1): 8-26. Accessed on October 12, 2018. Available online at https://doi.org/10.1111/j.17485991.2007.00002.x

Meuleman, Louis. 2018. Metagovernance for Sustainability: A Framework for Implementing the Sustainable Development Goals. London: Routledge.

Osborne, David and Ted Gaebler. 1992. Reinventing Government: How the Entrepreneurial Spirit is Transforming the Public Sector. Reading, MA: Addison-Wesley.

Ostrom, Elinor. 2010. "Beyond Markets and States: Polycentric Governance of Complex Economic Systems.” American Economic Review 100, 3: 641-72. Accessed on October 12, 2018. Available online at https://doi.org/10.1080/19186444.2010.11658229

Pattberg, Philipp. 2008. Private Institutions and Global Governance: The New Politics of Environmental Sustainability. Cheltenham: Edward Elgar.

Pierre, Jon and B. Guy Peters. 2000. Governance, Politics and the State. London: Macmillan.

Pollitt, Christopher and Geert Bouckaert. 2004. Public Management Reform: A Comparative Analysis. Oxford: Oxford University Press.

Raynolds, Laura and Elizabeth Bennett. 2016. Handbook of Research on Fair Trade. Cheltenham, UK: Edward Elgar.

Renard, Marie-Christine. 2003. "Fair Trade: Quality, Market and Conventions.” Journal of Rural Studies 19: 87-96. Accessed on October 12, 2018. Available online at https://doi.org/10.1016/S0743-0167(02)00051-7 
Rhodes, Rod. 1997. Understanding Governance: Policy Networks, Governance, Reflexivity, and Accountability. Buckingham: Open University Press.

Rose, Nikolas and Peter Miller. 1992. "Political Power beyond the State: Problematics of Government.” The British Journal of Sociology 43 (2): 173-205. Accessed on October 12, 2018. Available online at https://doi.org/10.1111/j.1468-4446.2009.01247.x

Seawright, Jason, and John Gerring. 2008. "Case Selection Techniques in Case Study Research: A Menu of Qualitative and Quantitative Options." Political Research Quarterly 61 (2): 294-308. Accessed on October 12, 2018. Available online at https://doi.org/10.1177/1065912907313077

Sørensen, Eva. 2006. "The Changing Role of Politicians in Processes of Democratic Governance." The American Review of Public Administration 36 (1): 98-114. Accessed on October 12, 2018. Available online at https://doi.org/10.1177/0275074005282584

Sørensen, Eva and Jacob Torfing. 2007. “Theoretical Approaches to Metagovernance.” In Theories of Democratic Network Governance, edited by Eva Sørensen and Jacob Torfing, 169-182. Basingstoke, UK: Palgrave Macmillan.

Synnott, Timothy. 2005. "Some Notes on the Early Years of FSC.” Accessed on January 11, 2016. Available online at https://ic.fsc.org/download.notes-on-the-early-years-offsc.a-797.pdf

Tollefson, Chris, Anthony Zito and Fred Gale. 2012. "Symposium Overview: Conceptualizing New Governance Arrangements." Public Administration 90 (1): 3-18. Accessed October 13, 2018. Available online at https://doi.org/10.1111/j.1467-9299.2011.02003.x

Torfing, Jacob, B. Guy Peters, Jon Pierre, and Eva Sørensen. 2012. Interactive Governance: Advancing the Paradigm. Oxford University Press, Oxford, UK 
Verbruggen, Paul, and Tetty Havinga. 2014. "The Rise of Transnational Private MetaRegulators.” Paper 5, Osgoode Legal Studies Research Paper Series, York University, Canada.

Wenban-Smith, Matthew. 2007. 'Certified Once, Accepted Everywhere': Is the International Accreditation Forum (IAF) Part of the Solution or Part of the Problem? Dovetail Partners. Accessed on March 4, 2016. Available online at http://accab.org/images/publication/05112014055639.pdf

WFTO (World Fair Trade Organization). 2014a. "Our Guarantee System.” Accessed on July 29, 2016. Available online at http://wfto.com/standard-and-guarantee-system/guaranteesystem

WFTO 2014b. "Who We Are." Accessed on July 29, 2016. Available online at http://wfto.com/about-us/who-we-are

\footnotetext{
${ }^{1}$ Fairtrade International, the term used in this article, is often referred to popularly as 'FLO'. Its legally registered name is 'Fairtrade Labelling Organizations International eV'. ${ }^{2}$ A complete list of Fairtrade International standards is available at URL: http://www.fairtrade.net/fileadmin/user_upload/content/2009/standards/documents/2015-1218_List_of_Fairtrade_Standards.pdf. [Last accessed 9 June 2016.]

${ }^{3}$ WFTO 2014a and WFTO 2014b. The WFTO's 10 principles of fair trade are available at URL: http://www.wfto.com/fair-trade/10-principles-fair-trade. The WFTO code of practice is available at URL: http://www.wfto.com/our-path-fair-trade/wfto-code-practice. [Last accessed 9 June 2016.]

${ }^{4}$ The charter is available at URL: http://www.wfto.com/fair-trade/charter-fair-tradeprinciples. [Last accessed 9 June 2016.]

${ }^{5}$ Synnott $(2005,14)$ states: "[ $t$ ]he [first Certification Working Group] meeting agreed that the FSC initiative should embrace all forest products, not only timber. FSC would also cover certification of forests in all parts of the world, not just tropical forests. The issue of whether and how plantations might be included was raised but not defined".

${ }^{6}$ The relevant FSC standard is: General requirements for FSC accredited certification bodies, FSC-STD-20-001 V4-0 EN, 9 November 2015.

${ }^{7}$ ASI is also the accreditation agency for Marine Stewardship Council, Aquaculture Stewardship Council and the Roundtable for Sustainable Palm Oil.

${ }^{8}$ This is detailed in Processing Complaints in the FSC® Certification Scheme FSC-PRO-01008 (V2-0) EN and Processing Appeals FSC-PRO-01-005 (V3-0) EN.
} 